\title{
Properties of Cu-Based Shape-Memory Alloys Prepared by Selective Laser Melting
}

\author{
T. Gustmann ${ }^{1}$ J. M. dos $\operatorname{Santos}^{2}$ • P. Gargarella ${ }^{2}$ U. Kühn ${ }^{1} \cdot$ J. Van Humbeeck ${ }^{3}$. \\ S. Pauly ${ }^{1}$
}

Published online: 5 December 2016

(C) ASM International 2016

\begin{abstract}
Two shape-memory alloys with the nominal compositions (in wt.\%) $\mathrm{Cu}-11.85 \mathrm{Al}-3.2 \mathrm{Ni}-3 \mathrm{Mn}$ and $\mathrm{Cu}-$ $11.35 \mathrm{Al}-3.2 \mathrm{Ni}-3 \mathrm{Mn}-0.5 \mathrm{Zr}$ were prepared by selective laser melting (SLM). The parameters were optimised to identify the process window, in which almost fully dense samples can be obtained. Their microstructures were analysed and correlated with the shape-memory behaviour as well as the mechanical properties. Suction-cast specimens were also produced for comparison. Mainly, $\beta_{1}{ }^{\prime}$ martensite forms in all samples, but $0.5 \mathrm{wt} . \%$ of $\mathrm{Zr}$ stabilises the $\mathrm{Y}$ phase $\left(\mathrm{Cu}_{2} \mathrm{AlZr}\right)$, and its morphology depends on the thermal history and cooling rate. After annealing, the $\mathrm{Y}$ phase is primarily found at the grain boundaries hampering grain coarsening. Due to the relative high cooling rates applied here, $\mathrm{Zr}$ is mostly dissolved in the martensite in the as-prepared samples and it has a grainrefining effect only up to a critical cooling rate. The $\mathrm{Zr}$ containing samples have increased transformation temperatures, and the $\mathrm{Y}$ phase seems to be responsible for the jerky martensite-to-austenite transformation. All the samples are relatively ductile because they mostly fracture in a transgranular manner, exhibiting the typical double
\end{abstract}

T. Gustmann

t.gustmann@ifw-dresden.de

$\triangle$ S. Pauly

s.pauly@ifw-dresden.de

1 IFW Dresden, Institute for Complex Materials, 01069 Dresden, Germany

2 Departamento de Engenharia de Materiais (DEMa), Universidade Federal de São Carlos (UFSCar), São Carlos, SP, Brazil

3 Department of Materials Engineering, KU Leuven, 3001 Leuven, Belgium yielding. Selective laser melting allows the adjustment of the transformation temperatures and the mechanical properties already during processing without the need of a subsequent heat treatment.

Keywords CuNiAl - Mechanical behaviour .

Transformation temperature $\cdot$ Ageing $\cdot$ Selective laser melting

\section{Introduction}

Shape-memory alloys (SMAs) are able to recover a shape change caused by plastic deformation on heating to above a critical temperature. This behaviour is known as shapememory effect (SME) [1-3]. It is related to the reversible transformation of a low-temperature phase (martensite) to a high-temperature phase (austenite), which can be stressinduced or temperature-induced [1-7]. The four characteristic temperatures of this diffusionless phase transformation are $A_{\mathrm{s}}, A_{\mathrm{f}}, M_{\mathrm{s}}$ and $M_{f} . A_{\mathrm{s}}$ represents the temperature at which austenite begins to form, and $A_{\mathrm{f}}$ is the temperature at which all martensite has transformed to austenite. On the other hand, austenite starts to transform during cooling $\left(M_{\mathrm{s}}\right)$ until only martensite is left $\left(M_{\mathrm{f}}\right)$. These temperatures basically define the temperature regime in which SMAs can be employed.

The probably most widely-used and -studied SMA so far, Ni-Ti, is generally deployable up to $80^{\circ} \mathrm{C}$ $[1-3,6,8-10]$. Extensive research has been devoted to increasing the transformation temperatures by developing new alloy compositions that can be applied at temperatures above $100{ }^{\circ} \mathrm{C}$, the so-called high-temperature shapememory alloys (HTSMAs) [1]. However, the HTSMAs based on Ni-Ti like Ti-Ni-Pd, Ti-Ni-Pt, Ni-Ti-Hf or Ni- 
$\mathrm{Ti}-\mathrm{Zr}$ are relatively expensive and difficult to manufacture [1]. For this reason, there is major interest in another group of HTSMAs derived from $\mathrm{Cu}$-based alloys (e.g. $\mathrm{Cu}-\mathrm{Zn}-\mathrm{Al}$ and $\mathrm{Cu}-\mathrm{Al}-\mathrm{Ni}$ ) due to their relatively low manufacturing costs, good processability as well as good shape-memory properties [1-6, 8-19].

Unfortunately, these alloys are inherently brittle in the polycrystalline state due to intergranular cracking, which is mainly caused by a high elastic anisotropy [2]. The anisotropy is more pronounced in coarse-grained $\mathrm{Cu}$-based SMAs, which are generally produced under relatively low cooling rates [2, 3, 9, 13, 15-17]. Slowly cooled Cu-based SMAs, moreover, tend to decompose eutectoidly into the brittle $\gamma_{2}$ phase. This imposes an additional restriction on the deformability and applicability of these alloys [2, 13]. Hence, especially $\mathrm{Cu}-\mathrm{Al}-\mathrm{Ni} \mathrm{SMAs}$, which are less prone to ageing (i.e. the precipitation of $\gamma_{2}$ or other phases) than $\mathrm{Cu}-\mathrm{Zn}-\mathrm{Al}$ SMAs for instance, with small grain sizes and enhanced deformability have been subject of research in the past decades $[2,4,7,9,10,18-20]$.

The propensity to early failure in coarse-grained $\mathrm{Cu}$ based SMAs can be avoided by selecting the proper processing conditions or alloy composition. It has been shown that the poor workability of $\mathrm{Cu}-\mathrm{Al}-\mathrm{Ni}$ SMAs caused by brittle intergranular fracture can be reduced by refining the microstructure through the addition of Co [10], Mn [9], Ti $[2,10-13,19,20]$ or $\mathrm{Zr}[2,13,14]$. When $\mathrm{Ti}$ or $\mathrm{Zr}$ is dissolved in the melt, it reduces the grain growth rate and thus refines the microstructure [19, 21, 22]. Moreover, already small amounts of Ti favour the precipitation of the so-called $\mathrm{X}$ phase $\left(\mathrm{Cu}_{2} \mathrm{ZrTi}\right)$ [23-25]. When $\mathrm{Zr}$ is added to some Cu-based SMAs instead, the isomorphous $\mathrm{Y}$ phase $\left(\mathrm{Cu}_{2} \mathrm{ZrAl}\right)$ forms $[20,26]$. These two phases can interact with the grain boundaries and reduce grain coarsening on annealing. In addition, they are known to affect the mechanical properties and the martensitic transformation [27-30] but the exact mechanisms are not fully understood to date.

An alternative route for grain refinement and the suppression of brittle phases in $\mathrm{Cu}$-based SMAs constitutes rapid solidification [4, 5, 20, 31]. Even though selective laser melting (SLM) has high intrinsic cooling rates [32], it is generally not considered to be a rapid solidification technique. SLM creates a bulk part layer by layer through melting of specific, predefined small volumes of powder $[5,6,31-38]$. The processing of a thin powder layer on a massive substrate plate in combination with small laser spot diameters (about $80 \mu \mathrm{m}$ ) results in a fast removal of the heat, comparable to rapid quenching [32]. The processing conditions have a strong impact on factors like chemical composition, ordering, phase formation and especially on the grain size. These factors, in turn, determine the details of the phase transformation
$[2,3,11,13,18,39]$. With decreasing grain size, the transformation temperatures of $\mathrm{Cu}$-based SMAs have been found to become lower $[2,4,5,10,16,18,20]$. This makes SLM a very attractive tool for processing $\mathrm{Cu}$-based SMAs because the resulting grain sizes are rather small and, hence, these specimens exhibit an improved deformability [7]. At the same time, sophisticated structures can also be produced by this approach, which are impossible to be created through casting [38]. One critical aspect of samples prepared by SLM, yet, is porosity. It can be relatively high compared to conventionally processed material, and it usually is detrimental for the mechanical properties, especially the ductility [34]. Therefore, the process parameters (energy input, $E_{\mathrm{v}}$ ) have to be adapted and optimised first for each alloy composition in order to ensure the production of almost defect-free samples.

The energy dissipated in the powder layer can be controlled by adjusting the laser power, the scanning speed and the spacing between two neighbouring tracks (hatching distance or track overlap) [32-36, 40]. In this way, the transformation temperatures of SMAs can be tailored to some extent due to different local solidification conditions $[6,37,41,42]$. Such a precise control of the solidification does not exist for conventional casting techniques.

The present study focuses on the fabrication of the two shape-memory alloys $\mathrm{Cu}-11.85 \mathrm{Al}-3.2 \mathrm{Ni}-3 \mathrm{Mn}$ and $\mathrm{Cu}-$ $11.35 \mathrm{Al}-3.2 \mathrm{Ni}-3 \mathrm{Mn}-0.5 \mathrm{Zr}$ (wt.\%) via selective laser melting. The SLM parameters of $\mathrm{Cu}-11.85 \mathrm{Al}-3.2 \mathrm{Ni}-3 \mathrm{Mn}$ samples with a high density [31] were transferred to the processing of $\mathrm{Cu}-11.35 \mathrm{Al}-3.2 \mathrm{Ni}-3 \mathrm{Mn}-0.5 \mathrm{Zr}$ and optimised. The microstructure and phase formation of compact parts are then correlated with the shape-memory behaviour as well as the mechanical properties and compared with other specimens obtained by suction casting, another quenching technique [43]. The present work helps to better understand the interrelation between the processing techniques, the SLM parameters, the phase formation and the evolution of the microstructures as well as the resulting properties of these Cu-based shape-memory alloys in terms of deformability and shape-memory behaviour.

\section{Experimental Procedure}

\section{Powder and Selective Laser Melting}

Gas-atomised $\mathrm{Cu}-11.85 \mathrm{Al}-3.2 \mathrm{Ni}-3 \mathrm{Mn}$ powder with particle sizes ranging between 30 and $90 \mu \mathrm{m}$ and $\mathrm{Cu}-11.35 \mathrm{Al}-$ $3.2 \mathrm{Ni}-3 \mathrm{Mn}-0.5 \mathrm{Zr}$ powder (particle sizes: $30-76 \mu \mathrm{m}$ ) were used. Both alloys were pre-fabricated as ingot using highpurity elements ( $>99.9$ wt. $\%$ ) in an induction furnace under argon atmosphere. A SLM $250^{\mathrm{HL}}$ system (SLM Solutions) equipped with a $400 \mathrm{~W} \mathrm{Nd:YAG} \mathrm{laser} \mathrm{operating} \mathrm{with} \mathrm{a}$ 
point distance of $200 \mu \mathrm{m}$ and an exposure time of $400 \mu \mathrm{s}$ was used in the present work. For more details, please refer to $[32,40]$. There is a constant flow of both powders in the feeding-system of the SLM $250^{\mathrm{HL}}$. This guarantees the required flowability of the powders during processing. The diameter of the laser beam was held constant at a value of $80 \mu \mathrm{m}$, and the process was carried out in argon atmosphere. The layer thickness was adjusted to $90 \mu \mathrm{m}$ for $\mathrm{Cu}-11.85 \mathrm{Al}-3.2 \mathrm{Ni}-3 \mathrm{Mn}$ and to $80 \mu \mathrm{m}$ for $\mathrm{Cu}-$ $11.35 \mathrm{Al}-3.2 \mathrm{Ni}-3 \mathrm{Mn}-0.5 \mathrm{Zr}$. Furthermore, the scanning vectors between two subsequent layers were rotated by $90^{\circ}$. Three parameter combinations were selected for the processing of cylindrical $\mathrm{Cu}-11.85 \mathrm{Al}-3.2 \mathrm{Ni}-3 \mathrm{Mn}$ samples with $3.2 \mathrm{~mm}$ in diameter and $8 \mathrm{~mm}$ in length [31]. For the fabrication of $\mathrm{Cu}-11.35 \mathrm{Al}-3.2 \mathrm{Ni}-3 \mathrm{Mn}-0.5 \mathrm{Zr}$ rods, the laser power $\left(P_{\mathrm{L}}\right)$, scanning speed $\left(v_{\mathrm{s}}\right)$ and hatching distance (track overlap, $h_{\mathrm{s}}$ ) were systematically varied between 300 and $350 \mathrm{~W}, 800-900 \mathrm{~mm} / \mathrm{s}$ and 15-50\% track overlap. In addition, both alloys were prepared by arc-melting in a Ti-gettered argon atmosphere (Edmund Bühler 2414). Ingots with a weight of 10-16 g were used to fabricate 70 -mm-long rods with a diameter of $3 \mathrm{~mm}$ and plates with the same length, a thickness of $2 \mathrm{~mm}$ and a width of $10 \mathrm{~mm}$ via suction casting into a water-cooled copper mould. One suction-cast rod was homogenised at $850{ }^{\circ} \mathrm{C}$ for $10 \mathrm{~min}$, quenched in water and subsequently aged at $300{ }^{\circ} \mathrm{C}$ for $60 \mathrm{~min}$ followed by cooling in air. The annealed sample serves as a reference state to better understand the phase formation, microstructure and martensitic transformation.

\section{Sample Characterisation}

The chemical composition of the powders and the bulk material was analysed using ICP-OES (Inductively-Coupled Plasma-Optical Emission Spectroscopy, IRIS Intrepid II XUV from Thermo Fischer Scientific). The oxygen (LECO TC-436DR) and hydrogen contents (HORIBA EMGA $621 \mathrm{~W}$ ) were measured as well. The density of the bulk specimens was obtained by the Archimedean method using a balance (Sartorius MC210P). Relative densities $\left(\rho_{\text {rel }}\right)$ were calculated from these values by relating them to the density of an induction-cast sample of $\mathrm{Cu}-11.85 \mathrm{Al}-$ $3.2 \mathrm{Ni}-3 \mathrm{Mn}\left(\rho=7.234 \mathrm{~g} / \mathrm{cm}^{3}\right)$ and a suction-cast sample of $\quad \mathrm{Cu}-11.35 \mathrm{Al}-3.2 \mathrm{Ni}-3 \mathrm{Mn}-0.5 \mathrm{Zr} \quad\left(\rho=7.289 \mathrm{~g} / \mathrm{cm}^{3}\right)$, which were found to be free of pores by means of computer tomography [31].

The powder as well as a slice from the bulk samples was characterised by X-ray diffraction using a STOE STADI P diffractometer with $\mathrm{Mo}-\mathrm{K}_{\alpha 1}$ radiation $(\lambda=0.07093187 \mathrm{~nm})$ in transmission mode. All bulk samples were cut and additionally ground with sandpaper (P240-P4000), polished to $1 \mu \mathrm{m}$, finally prepared with MasterMet 2 (Buehler) and etched for $13 \mathrm{~s}$ in a solution of $60 \mathrm{vol} . \% \mathrm{H}_{2} \mathrm{O}$ and $40 \mathrm{vol} . \% \mathrm{HNO}_{3}$. In order to investigate the microstructures, optical microscopy (Nikon Epiphot 300) and scanning electron microscopy (Gemini Leo 1530) were carried out. Grain size measurements were performed by determining the intercepts of vertical and horizontal lines with the grain boundaries (software ImageAccess, magnification 200:1). For the electron backscatter diffraction (EBSD) experiments, a NORDLYS detector was used (Oxford Instruments).

A minimum of two samples were cut from the bulk material for thermal analysis using a differential scanning calorimeter (Perkin Elmer DSC-7) at a heating/cooling rate of $10 \mathrm{~K} / \mathrm{min}$. The samples were held for $2 \mathrm{~min}$ at $40{ }^{\circ} \mathrm{C}$, subsequently heated to $180{ }^{\circ} \mathrm{C}\left(240{ }^{\circ} \mathrm{C}\right.$ for $\mathrm{Cu}-11.35 \mathrm{Al}-$ $3.2 \mathrm{Ni}-3 \mathrm{Mn}-0.5 \mathrm{Zr}$ ) and cooled back to $40{ }^{\circ} \mathrm{C}$.

In addition, hardness measurements were carried out with a 100-g load and a loading time of $10 \mathrm{~s}$ using a Vickers microhardness tester (Shimazu HMV-2000). Several indents were placed in the centre and near the surface of the samples. At least three tensile and compression tests were conducted for each sample using an Instron 5869 device at a strain rate of $5 \times 10^{-4} \mathrm{~s}^{-1}$. The strain was recorded by a laser extensometer (Fiedler Optoelektronik), and the compression test samples (rods) were machined to a diameter of $3 \mathrm{~mm}$ as well as ground to a height of $6 \mathrm{~mm}$. The tensile samples (suction-cast plates, SLM square blocks with $8 \mathrm{~mm}$ side length and $40 \mathrm{~mm}$ in height) were machined as flat tensile samples by electrical discharge machining.

\section{Results and Discussion}

The experimentally measured chemical composition of all samples is listed in Table 1. The powders as well as the bulk material obtained by SLM and suction casting show

Table 1 Nominal and experimentally determined chemical compositions of the two $\mathrm{Cu}$-based shape-memory powders, suction-cast rods and SLM specimens

\begin{tabular}{llllllll}
\hline & $\mathrm{Cu}$ & $\mathrm{Al}$ & $\mathrm{Ni}$ & $\mathrm{Mn}$ & $\mathrm{Zr}$ & $\mathrm{O}_{2}$ & $\mathrm{H}_{2}$ \\
\hline Nominal & 81.95 & 11.85 & 3.2 & 3.0 & - & - & - \\
Powder & 81.75 & 11.84 & 3.22 & 2.93 & - & 0.016 & $<0.001$ \\
Suction-cast & 81.95 & 11.83 & 3.21 & 2.82 & & 0.010 & \\
SLM & 81.79 & 11.84 & 3.21 & 2.90 & & 0.015 & \\
Nominal & 81.95 & 11.35 & 3.2 & 3.0 & 0.5 & - & - \\
Powder & 82.13 & 11.27 & 3.20 & 2.75 & 0.44 & 0.009 & $<0.001$ \\
Suction-cast & 81.83 & 11.36 & 3.18 & 2.94 & 0.51 & 0.004 & \\
SLM & 82.00 & 11.23 & 3.24 & 2.73 & 0.45 & 0.011 & \\
\hline All & & & & & & &
\end{tabular}

All values are in wt\%. The samples I-a and II-a (Table 2) were measured in case of the SLM processing 
Table 2 Overview of the suction-cast specimens and the selected parameters for the processing of $\mathrm{Cu}-11.85 \mathrm{Al}-3.2 \mathrm{Ni}-3 \mathrm{Mn}$ and $\mathrm{Cu}-11.35 \mathrm{Al}-$ $3.2 \mathrm{Ni}-3 \mathrm{Mn}-0.5 \mathrm{Zr}$ by SLM

\begin{tabular}{|c|c|c|c|c|c|c|c|}
\hline & Sample & $\begin{array}{l}\text { Scanning } \\
\text { speed }(\mathrm{mm} / \mathrm{s})\end{array}$ & $\begin{array}{l}\text { Track } \\
\text { overlap }(\%)\end{array}$ & $\begin{array}{l}\text { Energy input } \\
\left(\mathrm{J} / \mathrm{mm}^{3}\right)\end{array}$ & $\begin{array}{l}\text { Relative } \\
\text { Density }(\%)\end{array}$ & $l_{\mathrm{x}}(\mu \mathrm{m})$ & $l_{\mathrm{y}}(\mu \mathrm{m})$ \\
\hline \multirow[t]{4}{*}{$-0 \mathrm{Zr}$} & Suction-cast & - & - & - & $99.5 \pm 0.7$ & $51 \pm 9$ & $58 \pm 3$ \\
\hline & SLM (I-a) & 740 & 30 & 38.1 & $98.9 \pm 0.1$ & $33 \pm 20$ & $33 \pm 28$ \\
\hline & SLM (I-b) & 800 & 30 & 38.2 & $98.8 \pm 0.2$ & $31 \pm 22$ & $28 \pm 26$ \\
\hline & SLM (I-c) & 740 & 15 & 30.9 & $98.8 \pm 0.1$ & $30 \pm 21$ & $36 \pm 26$ \\
\hline \multirow[t]{5}{*}{$-0.5 \mathrm{Zr}$} & Suction-cast (surface) & - & - & - & $100 \pm 0.5$ & $26 \pm 10$ & $14 \pm 5$ \\
\hline & Suction-cast (centre) & - & - & - & & $50 \pm 8$ & $44 \pm 4$ \\
\hline & SLM (II-a) & 740 & 30 & 42.9 & $99.2 \pm 0.1$ & $29 \pm 18$ & $35 \pm 26$ \\
\hline & SLM (II-b) & 800 & 30 & 39.7 & $99.4 \pm 0.4$ & $28 \pm 20$ & $31 \pm 25$ \\
\hline & SLM (II-c) & 740 & 40 & 50.7 & $99.8 \pm 0.3$ & $31 \pm 20$ & $38 \pm 29$ \\
\hline
\end{tabular}

The laser power was $330 \mathrm{~W}$ and the layer thickness $90 \mu \mathrm{m}(\mathrm{Cu}-11.85 \mathrm{Al}-3.2 \mathrm{Ni}-3 \mathrm{Mn})$ or $80 \mu \mathrm{m}(\mathrm{Cu}-11.35 \mathrm{Al}-3.2 \mathrm{Ni}-3 \mathrm{Mn}-0.5 \mathrm{Zr})$. The transformation temperatures are listed in Table 3. The linear intercepts $I$ ( $n=10$ lines) were recorded perpendicular to the building direction in two directions $(x$ and $y)$

only slight deviations from the nominal composition and no significant uptake of oxygen or hydrogen.

\section{Processing of $\mathrm{Cu}-11.35 \mathrm{Al}-3.2 \mathrm{Ni}-3 \mathrm{Mn}-0.5 \mathrm{Zr}$ by SLM}

The optimum SLM parameters for producing quaternary $\mathrm{Cu}-11.85 \mathrm{Al}-3.2 \mathrm{Ni}-3 \mathrm{Mn}$ samples have already been established in our previous work [31]. These parameters (e.g. $P_{\mathrm{L}}=330 \mathrm{~W}, \quad v_{\mathrm{s}}=740 \mathrm{~mm} / \mathrm{s}, \quad 30 \%$ track overlap, $\left.\rho_{\text {rel }}=98.9 \%\right)$ were first applied to $\mathrm{Cu}-11.35 \mathrm{Al}-3.2 \mathrm{Ni}-$ $3 \mathrm{Mn}-0.5 \mathrm{Zr}$ (sample II-a in Table 2). Usually, the SLM process is very sensitive to changes in the composition of the powder or the powder particle sizes. Therefore, the transferability of process parameters is often limited [33, 40, 44]. In order to assess the optimal process window for the $\mathrm{Zr}$ containing alloy, the laser power, the scanning speed and the track overlap were systematically varied. Combinations of laser powers between 300 and $350 \mathrm{~W}\left(v_{\mathrm{s}}=740 \mathrm{~mm} / \mathrm{s}, 30 \%\right.$ track overlap), scanning speeds between 800 and $900 \mathrm{~mm} / \mathrm{s}$ $\left(P_{\mathrm{L}}=330 \mathrm{~W}, 30 \%\right.$ track overlap) and track overlaps between 15 and $50 \%\left(P_{\mathrm{L}}=330 \mathrm{~W}, v_{\mathrm{s}}=740 \mathrm{~mm} / \mathrm{s}\right)$ yielded samples with a relative density in the range of $98-99.8 \%$. The optimum parameters, together with the energy dissipated in the material and the resulting densities are summarised in Table 2. The relative density of $\mathrm{Cu}-11.35 \mathrm{Al}-3.2 \mathrm{Ni}-3 \mathrm{Mn}-$ $0.5 \mathrm{Zr}$ (sample II-a) was found to be slightly higher $\left(\rho_{\text {rel, II- }}\right.$ $\mathrm{a}=99.2 \%$ ) than that of $\mathrm{Cu}-11.35 \mathrm{Al}-3.2 \mathrm{Ni}-3 \mathrm{Mn}$ (sample $\mathrm{I}-\mathrm{a}, \rho_{\text {rel,I-a }}=98.9 \%$ ) when produced under identical conditions. Due to the smaller particle size of the $\mathrm{Zr}$-containing alloy powder and the resulting lower layer thickness (about $80 \mu \mathrm{m}$ ), the energy input is somewhat higher (sample $\mathrm{I}-\mathrm{a}=38.1 \mathrm{~J} / \mathrm{mm}^{3}$ and sample II-a $=42.9 \mathrm{~J} / \mathrm{mm}^{3}$ ) and this seems to promote the fusion of the powder and thus the density of the samples [44]. If the energy input is increased further (sample II-c $=50.7 \mathrm{~J} / \mathrm{mm}^{3}$ ), the relative density reaches about $99.8 \%$. A similar relation between a higher energy input (by a higher track overlap in this case) and an increasing density has been also found in other studies [45]. Here, both $\mathrm{Cu}$-based alloys exhibit a high relative density only when the laser power reaches relatively large values of about $330 \mathrm{~W}$, which improves melting [35, 36].

\section{Phase Formation and Microstructure of $\mathrm{Cu}-$ 11.85Al-3.2Ni-3Mn and $\mathrm{Cu}-11.35 \mathrm{Al}-3.2 \mathrm{Ni}-3 \mathrm{Mn}-$ $0.5 \mathrm{Zr}$}

The phase formation in both alloys processed by suction casting and SLM was analysed by means of X-ray diffraction, and only $\beta_{1}{ }^{\prime}$ martensite $\left(P 2_{1} / m\right.$, [46]) was found, irrespective of the processing route and the composition (Fig. 1). This is in agreement with other reports on alloys with similar compositions [4, 5, 7, 31, 47], however, due to the detection limit of the XRD technique (generally a few wt.\% [48]), we cannot exclude that very small volume fractions of additional phases are present. Apparently, the applied cooling rates are sufficiently high to suppress the formation of the $\gamma_{2}$ and $\alpha$ phase. And since the martensite start temperature, $M_{\mathrm{s}}$, of $\mathrm{Cu}-11.85 \mathrm{Al}-3.2 \mathrm{Ni}-$ $3 \mathrm{Mn}$ is around $100{ }^{\circ} \mathrm{C}[20]$, the martensitic transformation is completed at room temperature. Despite the relatively high cooling rates during casting and selective laser melting, the bcc austenite can order into a $\mathrm{DO}_{3}$ structure on cooling, which then transforms to the observed $\beta_{1}{ }^{\prime}$ martensite [2, 49].

The austenite-to-martensite transformation also occurs in the quinary alloy during cooling, apparently leaving a fully martensitic microstructure $\left(\beta_{1}{ }^{\prime}\right)$ at room temperature. Only 


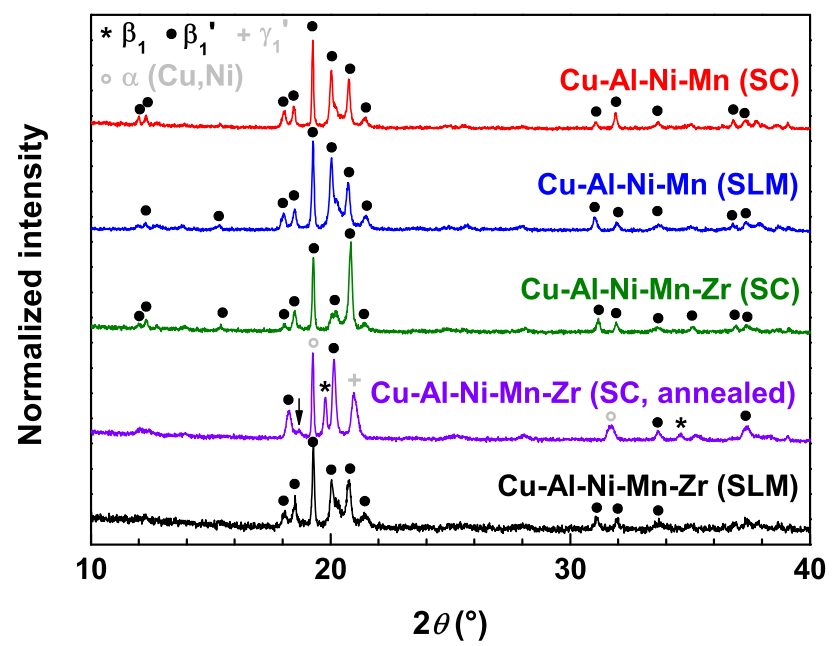

Fig. 1 X-ray diffraction pattern of $\mathrm{Cu}-11.85 \mathrm{Al}-3.2 \mathrm{Ni}-3 \mathrm{Mn}$ and $\mathrm{Cu}-$ $11.35 \mathrm{Al}-3.2 \mathrm{Ni}-3 \mathrm{Mn}-0.5 \mathrm{Zr}$ as $\operatorname{SLM}\left(P_{\mathrm{L}}=330 \mathrm{~W}, v_{\mathrm{s}}=740 \mathrm{~mm} / \mathrm{s}\right.$, $30 \%$ track overlap) and suction-cast (SC) sample. The main reflections belong to $\beta_{1}{ }^{\prime}$ martensite. The arrow marks a reflection, which most likely stems from $\mathrm{Cu}_{2} \mathrm{ZrAl}$

in the annealed sample, new reflections appear in the diffraction pattern. It is important to mention that an unambiguous phase identification by means of XRD is impossible here due to the pronounced texture of the samples, the relatively broad reflections and the abundance of possible stable or metastable phases having many overlapping peak positions $\left(\alpha, \gamma_{2}, \mathrm{NiAl}, \beta_{1}, \beta_{1}{ }^{\prime}\right.$ and $\left.\gamma_{1}{ }^{\prime}\right)$. A new reflection at $2 \theta=31.7^{\circ}$, at which an $\alpha$ reflection is expected, seems to indicate the eutectoid decomposition of the shape-memory alloy. And since the strongest $\alpha$ reflection coincides with the strongest $\beta_{1}{ }^{\prime}$ reflection, it cannot be excluded that $\alpha$ has precipitated. The resulting enrichment of $\mathrm{Al}$ in the remaining martensite might have then caused the local formation of $\gamma_{1}{ }^{\prime}$ (Pmmn) $[49,50]$ leading to the reflection near $2 \theta=21^{\circ}$. This peak is not found in the other diffraction patterns. However, it seems more likely that this particular reflection is a strongly shifted $\beta_{1}{ }^{\prime}$ martensite reflection and, moreover, that $\alpha$ has not yet begun to precipitate. $\mathrm{Cu}-\mathrm{Al}-\mathrm{Ni}$ alloys are known to be generally quite resistant against ageing [50,51], so the presence of $\alpha, \gamma_{2}$ and $\mathrm{NiAl}$ in the present annealed specimen is questionable. This hypothesis is corroborated by the fact that the Al content in the annealed suction-cast rod is identical within the experimental error $(9.8 \pm 0.1 \mathrm{wt} . \%)$ in all the samples (SLM, suction-cast rod and the annealed suction-cast rod). This could not apply if phases like $\alpha, \gamma_{2}$, $\mathrm{NiAl}$ or the $\mathrm{Y}$ phase had formed. Furthermore, the additional reflections in the diffraction pattern of the annealed sample match the austenite positions and thus appear to stem from residual $\beta_{1}$. The arrow in Fig. 1 marks another diffraction peak, which only appears after annealing. As we will discuss below, this reflection most likely proves the presence of the so-called $\mathrm{Y}$ phase $\left(\mathrm{Cu}_{2} \mathrm{ZrAl}, F m \overline{3} m\right)$ [20, 21].
In the following, we focus on the microstructures of the two alloys prepared by suction casting and selective laser melting. The grains of suction-cast $\mathrm{Cu}-11.85 \mathrm{Al}-3.2 \mathrm{Ni}-$ $3 \mathrm{Mn}$ have a relatively uniform size across the sample (intercept lengths along $x$ and $y: l_{\mathrm{x}}=51 \pm 9 \mu \mathrm{m}, l_{\mathrm{y}}=$ $58 \pm 9 \mu \mathrm{m})$ (Fig. 2a; Table 2). The inset depicts the martensite laths at a higher magnification, and there is no allusion to additional phases. In the case of the cast $\mathrm{Cu}-$ $11.35 \mathrm{Al}-3.2 \mathrm{Ni}-3 \mathrm{Mn}-0.5 \mathrm{Zr}$ rod, the grain size as well as the grain shape varies along the diameter (not shown here). The relatively fine grains $\left(l_{\mathrm{x}}=26 \pm 10 \mu \mathrm{m}, l_{\mathrm{y}}=14 \pm\right.$ $5 \mu \mathrm{m})$ near the surface are slightly elongated in the direction of the heat flow. The grains near the centre (Fig. 2b) are almost equiaxed, and their size is comparable to those of the suction-cast alloy without $\mathrm{Zr}$ (Table 2). The addition of $\mathrm{Zr}$, thus, has a pronounced grain-refining effect as it is also known from other studies $[13,14,19,20]$. The martensite laths are not as clearly visible as in the case of the Zr-free alloy (Fig. 2a, b), and particles with a size below $1 \mu \mathrm{m}$ can be found uniformly distributed in the grains (see also inset). EDX measurements reveal that these particles are enriched in $\mathrm{Zr}$, but more details can be only obtained after annealing (see below).

In contrast, the SLM specimens of both alloys contain relatively small grains (Table 2 ) due to the high cooling rates during processing $[6,32,37,52]$. The $\mathrm{Cu}-11.85 \mathrm{Al}-$ 3.2Ni-3Mn SLM sample (Fig. 2c) exhibits a "bimodal" grain size distribution [53] with equiaxed grains having diameters in the range of $10-30 \mu \mathrm{m}$ in the regions where the melt tracks overlap. In the centre of the melt tracks, the grains are elongated perpendicular to the scanning direction and have typical sizes of about $30-80 \mu \mathrm{m}$. This phenomenon is typical of the SLM process [5, 7, 31, $38,41,42]$, and it also applies to $\mathrm{Cu}-11.35 \mathrm{Al}-3.2 \mathrm{Ni}-3 \mathrm{Mn}-$ $0.5 \mathrm{Zr}$. Interestingly, an overall effect of $\mathrm{Zr}$ on the average grain size for samples prepared by SLM is not measureable, contrary to the specimens processed by suction casting (Table 2). The intercept lengths of sample I-a $\left(P_{\mathrm{L}}=330 \mathrm{~W}, v_{\mathrm{s}}=740 \mathrm{~mm} / \mathrm{s}, 30 \%\right.$ track overlap $)$ are almost equal to those of $\mathrm{Cu}-11.35 \mathrm{Al}-3.2 \mathrm{Ni}-3 \mathrm{Mn}-0.5 \mathrm{Zr}$ processed with the same parameters (sample II-a). Hence, $\mathrm{Zr}$ seems to become ineffective as a grain-refining agent at high cooling rates. The inset of Fig. $2 \mathrm{c}$ shows the fine martensite laths in the $\mathrm{Cu}-11.85 \mathrm{Al}-3.2 \mathrm{Ni}-3 \mathrm{Mn}$ sample processed by SLM. At a high magnification in the $\mathrm{Cu}-$ 11.35Al-3.2Ni-3Mn-0.5Zr SLM sample (inset of Fig. 2d), small precipitates with a typical size below $100 \mathrm{~nm}$ can be seen.

After annealing the suction-cast $\mathrm{Cu}-11.35 \mathrm{Al}-3.2 \mathrm{Ni}-$ $3 \mathrm{Mn}-0.5 \mathrm{Zr}$ rod, the grains become equiaxed $\left(l_{\mathrm{x}}=25 \pm 6 \mu \mathrm{m}, l_{\mathrm{y}}=23 \pm 8 \mu \mathrm{m}\right)$ and the microstructural gradient vanishes (not shown here). Moreover, second phase particles with typical sizes between 5 and $10 \mu \mathrm{m}$ 
Fig. 2 Optical micrographs of the cross-sectional microstructure of the suctioncast rods (3 $\mathrm{mm}$ in diameter) of a $\mathrm{Cu}-11.85 \mathrm{Al}-3.2 \mathrm{Ni}-3 \mathrm{Mn}$ and b $\mathrm{Cu}-11.35 \mathrm{Al}-3.2 \mathrm{Ni}-3 \mathrm{Mn}-$ $0.5 \mathrm{Zr}$ taken from the centre. $\mathbf{c}$ and $\mathbf{d}$ represent $\mathrm{Cu}-11.85 \mathrm{Al}-$ $3.2 \mathrm{Ni}-3 \mathrm{Mn}$ and $\mathrm{Cu}-11.35 \mathrm{Al}-$ $3.2 \mathrm{Ni}-3 \mathrm{Mn}-0.5 \mathrm{Zr}$ samples obtained by SLM (perpendicular to the building direction), respectively. The insets show magnifications of the microstructure (SEM). In both $\mathrm{Zr}$-containing alloys, a finely dispersed second phase is present
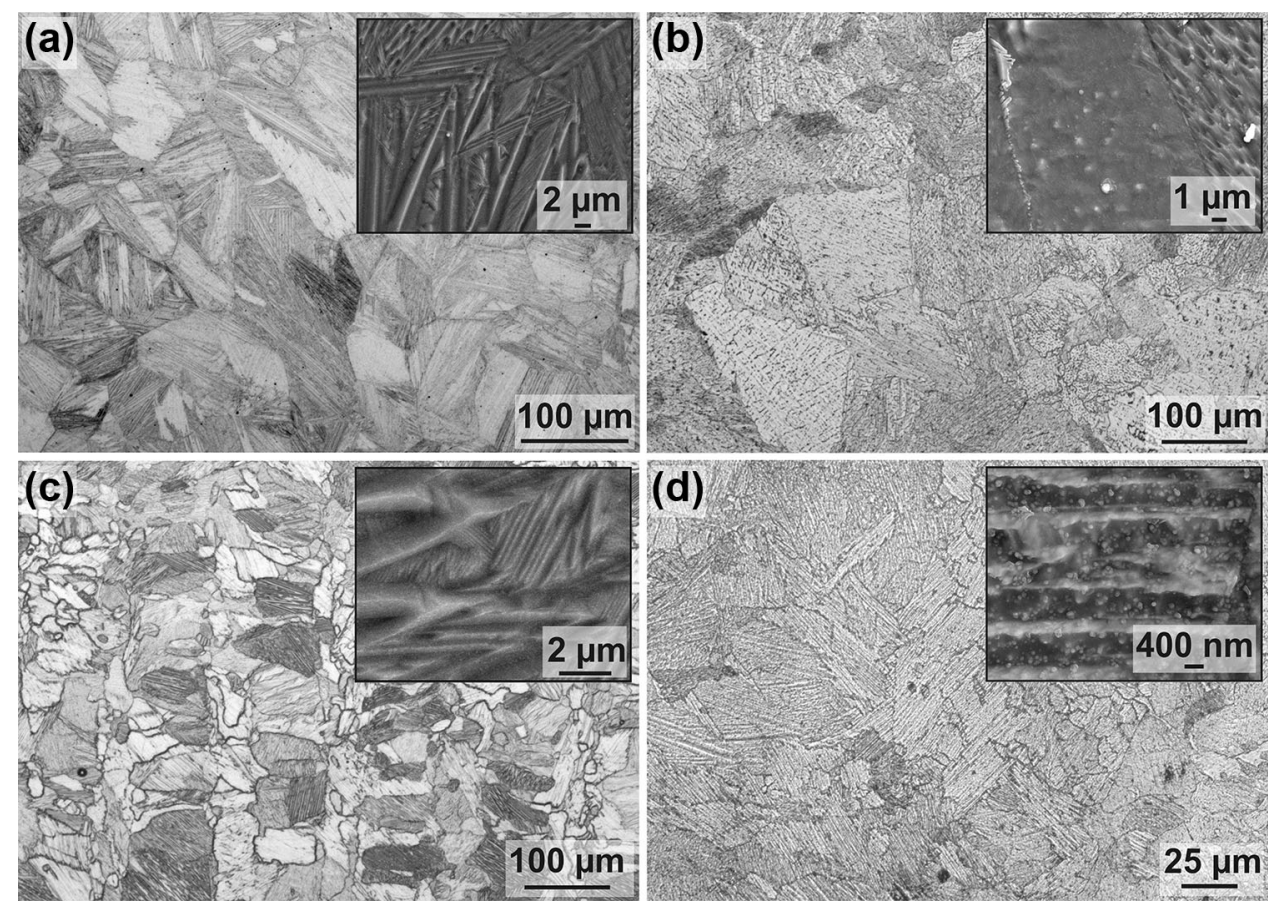

preferentially form at grain boundaries (Fig. 3). The EDX measurements on these particles suggest a $\mathrm{Cu}: \mathrm{Zr}: \mathrm{Al}$ ratio of 2:1:1. We performed complementary EBSD measurements (inset to Fig. 3), and while the matrix could be identified as $\beta_{1}{ }^{\prime}$ martensite (see XRD results), the particles belong to the $\mathrm{Cu}_{2} \mathrm{ZrAl}$ phase $(F m \overline{3} m)$, the so-called $\mathrm{Y}$ phase. We could neither detect any products of the eutectoid decomposition nor $\gamma_{1}{ }^{\prime}$ in this part of the sample. This

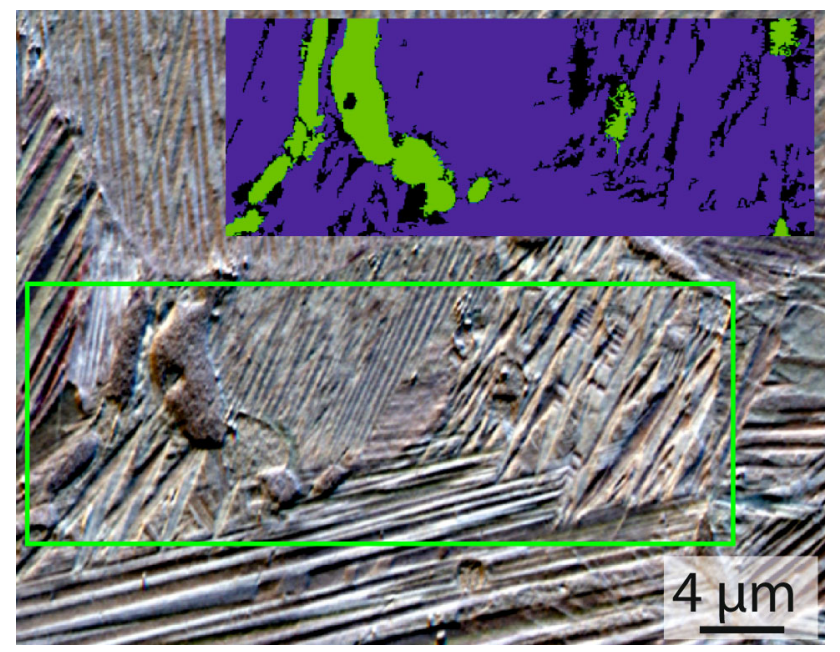

Fig. 3 Optical micrograph of the suction-cast $\mathrm{Cu}-11.35 \mathrm{Al}-3.2 \mathrm{Ni}-$ $3 \mathrm{Mn}-0.5 \mathrm{Zr}$ alloy. The box indicates the region of the sample, which was chosen for an EBSD measurement (see inset). The purple colour reflects $\beta_{1}{ }^{\prime}$ martensite, and the green colour represents the Y phase. The black regions could not be ascribed to either phase also due to limited pattern quality (Color figure online) affirms our assumption that the alloy has not yet begun to decompose into the low-temperature equilibrium phases. These findings help to understand the role of $\mathrm{Zr}$ and the $\mathrm{Y}$ phase for grain refinement in the present alloys. Due to the different cooling rates, $\mathrm{Zr}$ is dissolved to varying degrees in the grains after processing (suction-cast rod: $0.12 \pm 0.1$ wt.\% Zr, SLM: $0.43 \pm 0.05$ wt.\% Zr). The higher $\mathrm{Zr}$ content is accompanied by the presence of very fine Y-phase particles (Fig. 2d). When the samples are cooled at lower rates, the supersaturated matrix can precipitate larger Y-phase particles and also their volume fraction must increase. Since the Y phase is not particularly concentrated at the grain boundaries (Figs. 2b, d), it is not very likely that its presence is responsible for the reduced grain size. Instead, the dissolved $\mathrm{Zr}$ seems to slow down the grain growth [19, 21, 22]. It has been suggested [19] that if the concentration of $\mathrm{Ti}$ is above the solubility limit in a $\mathrm{Cu}-\mathrm{Al}-\mathrm{Ni}$ alloy, it does not have a grain-refining effect anymore. The same seems to also hold for $\mathrm{Zr}$. During the subsequent annealing treatment of the as-cast rod, however, the $\mathrm{Y}$ phase coarsens and strongly segregates at the grain boundaries (Fig. 3). It then pins the grain boundaries, hampers their movement and consequently reduces the grain size during recrystallization [22, 54] or slows down grain coarsening [24] as is also observed here.

\section{Martensitic Transformation}

The transformation temperatures of $\mathrm{Cu}-11.85 \mathrm{Al}-3.2 \mathrm{Ni}-$ $3 \mathrm{Mn}$ and $\mathrm{Cu}-11.35 \mathrm{Al}-3.2 \mathrm{Ni}-3 \mathrm{Mn}-0.5 \mathrm{Zr}$ produced by 


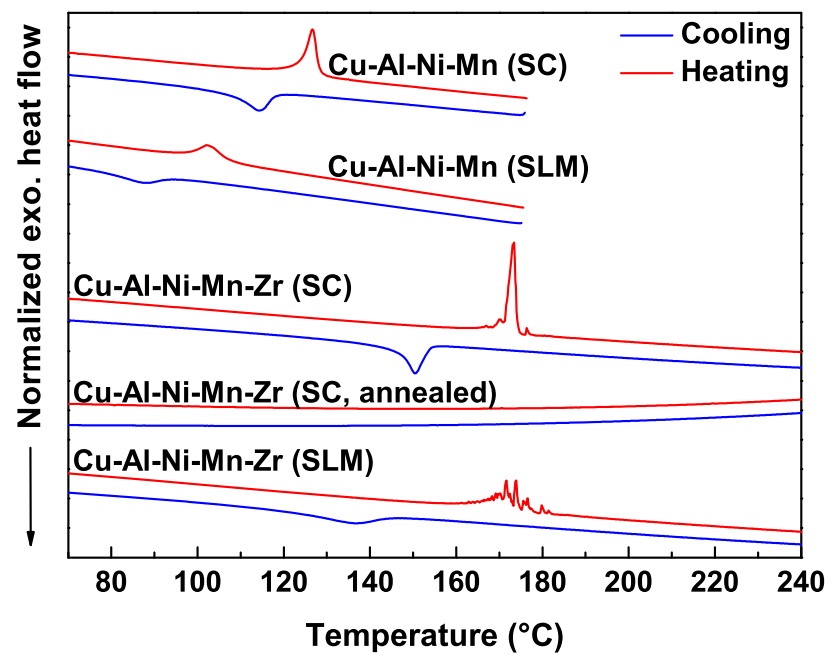

Fig. 4 DSC traces of $\mathrm{Cu}-11.85 \mathrm{Al}-3.2 \mathrm{Ni}-3 \mathrm{Mn}$ (SLM sample I-a and suction-cast, $\mathrm{SC}$ ) and $\mathrm{Cu}-11.35 \mathrm{Al}-3.2 \mathrm{Ni}-3 \mathrm{Mn}-0.5 \mathrm{Zr}$ (SLM sample II-a and suction-cast, SC). The curves show the phase transformation in the second cycle. The processing route determines the transformation temperatures, and the addition of $\mathrm{Zr}$ leads to a jerky reverse transformation. The annealed sample does not transform in the present temperature regime anymore

suction casting and SLM were measured, and in Fig. 4, the resulting DSC curves on heating and cooling are shown. Not only the microstructure is affected by the addition of $\mathrm{Zr}$ but also the transformation behaviour. The forward and reverse transformation for the $\mathrm{Zr}$-containing alloy generally occur at higher temperatures than for the $\mathrm{Zr}$-free alloy (Fig. 4; Table 3), which most likely originates from the lower Al content in the quinary alloy [49]. One might expect that the gradual precipitation of the $\mathrm{Y}$ phase additionally depletes the matrix in $\mathrm{Al}$. Interestingly, the $\mathrm{Al}$ content is identical $(9.8 \pm 0.1 \mathrm{wt} . \%)$ for the SLM sample and the suction-cast sample, as mentioned above. In the case of $\mathrm{Cu}-11.35 \mathrm{Al}-3.2 \mathrm{Ni}-3 \mathrm{Mn}-0.5 \mathrm{Zr}$, the reverse transformation is of jerky nature, which is especially obvious for the SLM sample (Fig. 4). This behaviour has been reported for various other $\mathrm{Cu}$-based SMAs [55-58] and has been ascribed to the $\gamma_{1}{ }^{\prime} \rightarrow \beta_{1}$ transformation [59, 60]. However, the only martensite detected in the present as-prepared samples is $\beta_{1}{ }^{\prime}$. Consequently, the jerky reverse martensitic transformation must be of different origin.

When a $\mathrm{Cu}-13 \mathrm{Al}-4 \mathrm{Ni}$ alloy is aged, the formerly smooth reverse transformation gradually becomes jerky [61]. At the later stages of ageing, small, coherent particles can be observed, which distort the lattice [61]. These particles are obstacles for the movement of the interfaces during the transformation, and the temporary pinning of the advancing interfaces leads to the jerky DSC trace [61]. Also, $\mathrm{Cu}_{2} \mathrm{ZrTi}$ (X phase) precipitates in $\mathrm{Cu}-11.9 \mathrm{Al}-5 \mathrm{Ni}-$ 2Mn-1Ti have been suggested to pin the interfaces [28]. Therefore, we propose here that the jerky reverse transformation in the present $\mathrm{Zr}$-containing alloy results from the presence of the $\mathrm{Y}$ phase. When it is finely dispersed as in the case of the SLM sample (Fig. 2d), it appears to be especially efficient in pinning the moving interfaces during the martensitic transformation and the transformation consists of many spikes (Fig. 4).

When the present suction-cast $\mathrm{Cu}-11.35 \mathrm{Al}-3.2 \mathrm{Ni}-$ $3 \mathrm{Mn}-0.5 \mathrm{Zr}$ rod is annealed, the martensitic transformation does not occur in the investigated temperature range $\left(80-240{ }^{\circ} \mathrm{C}\right.$ ) anymore (Fig. 4). Again, this cannot be caused by a depletion of $\mathrm{Al}$ in the matrix accompanying the precipitation and growth of the $\mathrm{Y}$ phase because the $\mathrm{Al}$ concentration is identical in all samples. Also an increasing degree of ordering could account for an increase in the transformation temperatures $[62,63]$. In the as-prepared state, the degree of ordering might be lower owing to the high cooling rates. During annealing, the ordering is fully restored leading to higher transformation temperatures. To rule this out, one annealed sample was heated to about $800{ }^{\circ} \mathrm{C}$ (not shown here), and apart from an endothermic reaction at $500{ }^{\circ} \mathrm{C}$ indicating a transition from $\mathrm{DO}_{3}$ to $\mathrm{B} 2$ ordering, no additional phase transformations could be found. The disappearing of the martensitic transformation might thus be related to the coarsening of the $\mathrm{Y}$ phase (Fig. 3). At the later stage of precipitation, the relatively coarse $\mathrm{Y}$ phase seems to be capable of completely suppressing the martensitic transformation, which is in agreement with other publications [61]. So, the current experiments strongly suggest a pronounced influence of the $\mathrm{Y}$ phase on the kinetics of the martensitic transformation.

After the addition of $\mathrm{Zr}$, the thermal hysteresis between the forward and reverse transformation $\left(T_{\mathrm{H}}\right)$ increases (Fig. 4, Table 3). In order to be able to better compare the different samples with each other, the equilibrium temperature $\left(T_{0}\right)$ between the martensite and the austenite phase was calculated for both alloys [10]:

$T_{0}=\frac{1}{2}\left(M_{\mathrm{s}}+A_{\mathrm{f}}\right)$.

The higher $T_{0}$ is, the more stable the martensitic phase is. $T_{0}$ increases after the addition of $\mathrm{Zr}$, and the maximum of $T_{0}$ is observed for the specimens processed by suction casting and for the samples that were fabricated by SLM (II-c) with an energy input of $50.7 \mathrm{~J} / \mathrm{mm}^{3}$ (Table 3). Furthermore, the DSC measurements reveal that the transformation temperatures of $\mathrm{Cu}-11.85 \mathrm{Al}-3.2 \mathrm{Ni}-3 \mathrm{Mn}$ and $\mathrm{Cu}-$ $11.35 \mathrm{Al}-3.2 \mathrm{Ni}-3 \mathrm{Mn}-0.5 \mathrm{Zr}$ alloys can be controlled during selective laser melting by modifying the energy input. In Fig. 5, the peak value of the austenite-to-martensite transformation is correlated with the energy dissipated in the samples during the SLM process. The energy input $\left(E_{v}\right)$ during the SLM process can be estimated by $[31,64]$ : 


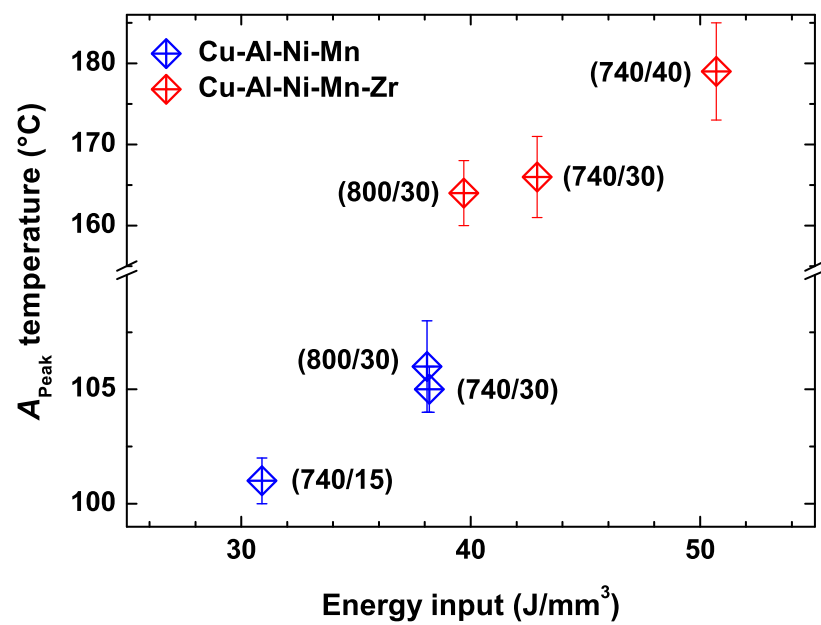

Fig. 5 Dependence of the transformation temperature $\left(A_{\text {peak }}\right)$ of $\mathrm{Cu}-$ $11.85 \mathrm{Al}-3.2 \mathrm{Ni}-3 \mathrm{Mn}$ and $\mathrm{Cu}-11.35 \mathrm{Al}-3.2 \mathrm{Ni}-3 \mathrm{Mn}-0.5 \mathrm{Zr}$ on the energy input during SLM processing. The peak value (martensiteto-austenite, second cycle) was used because it could be determined more precisely. The different values correspond to the samples as listed in Tables 2, 3. The values in the brackets denote the scanning speed in $\mathrm{mm} / \mathrm{s}$ and the track overlap in \%

$E_{\mathrm{V}}=\frac{P_{\mathrm{L}}}{\left(v_{\mathrm{s}} \cdot h_{\mathrm{s}} \cdot t_{\mathrm{z}}\right)}$,

where $P_{\mathrm{L}}$ is the laser power, $v_{\mathrm{s}}$ is the scanning speed, $h_{\mathrm{s}}$ is the hatching distance and $t_{\mathrm{z}}$ is the layer thickness. The layer thickness $(90 \mu \mathrm{m}$ for $\mathrm{Cu}-11.85 \mathrm{Al}-3.2 \mathrm{Ni}-3 \mathrm{Mn}$ or $80 \mu \mathrm{m}$ for $\mathrm{Cu}-11.35 \mathrm{Al}-3.2 \mathrm{Ni}-3 \mathrm{Mn}-0.5 \mathrm{Zr}$ ) and the laser power $(330 \mathrm{~W})$ were kept constant while the scanning speed and the track overlap were varied. The latter was modified much more strongly than the scanning speed, and this reflects in the overall energy dissipated during the SLM process (Table 2; Fig. 5). There is an obvious increase in the peak value with increasing the energy input during SLM processing for both alloys. A similar effect has been reported for Ni-Ti $[6,37,41,42]$. The change in the transformation temperatures can be explained by the concentration of quenched-in defects [37, 39] and the degree of ordering [65], which are determined by the applied cooling rates. Simultaneously, the cooling rate affects the grain size (intercept lengths), and it has been demonstrated that the grain size also has a strong influence on the martensitic transformation $[4,20,42,66]$. More specifically, some SMAs have been reported to obey a HallPetch-type relation [20]. In the present alloys, a similar trend seems to apply, but due to the scattering of grain sizes (Table 2) caused by the gradients in the cooling rate, it is difficult to unequivocally correlate the grain size with the transformation temperatures. And even though the energy input only is an indirect measure for factors like ordering, grain size or concentration of quenched-in defects, the result demonstrates that one can adjust the transformation properties of $\mathrm{Cu}$-based SMAs during selective laser melting. A subsequent thermo-mechanical treatment is not required anymore.

\section{Mechanical Properties}

In the next step, selected suction-cast samples and those SLM specimens with the highest relative density were subjected to tensile and compression tests as well as to hardness measurements. As the corresponding XRD patterns suggest, all samples are fully martensitic $\left(\beta_{1}{ }^{\prime}\right)$ and the results are summarised in Table 4.

For both alloys, the hardness observed in the SLM samples is higher compared to the suction-cast material. It can be assumed that internal stresses, usually generated during SLM [34, 35, 40, 42, 44, 52], are responsible for the increase in the hardness values. Furthermore, there is a general increase of the microhardness in the $\mathrm{Zr}$-containing alloy. The hardness of the suction-cast material increases from $210 \pm 22$ to $235 \pm 8 \mathrm{HVO} .1$, and the values for the SLM specimens are rising from $245 \pm 20$ (sample I-a) to
Table 3 Transformation temperatures of the SLM and the suction-cast material of $\mathrm{Cu}-$ $11.85 \mathrm{Al}-3.2 \mathrm{Ni}-3 \mathrm{Mn}$ and $\mathrm{Cu}-$ $11.35 \mathrm{Al}-3.2 \mathrm{Ni}-3 \mathrm{Mn}-0.5 \mathrm{Zr}$

\begin{tabular}{|c|c|c|c|c|c|c|c|c|}
\hline Sample & $A_{\mathrm{s}}\left({ }^{\circ} \mathrm{C}\right)$ & $A_{\mathrm{f}}\left({ }^{\circ} \mathrm{C}\right)$ & $A_{\text {peak }}\left({ }^{\circ} \mathrm{C}\right)$ & $M_{\mathrm{s}}\left({ }^{\circ} \mathrm{C}\right)$ & $M_{\mathrm{f}}\left({ }^{\circ} \mathrm{C}\right)$ & $M_{\text {peak }}\left({ }^{\circ} \mathrm{C}\right)$ & $T_{\mathrm{H}}\left({ }^{\circ} \mathrm{C}\right)$ & $T_{0}\left({ }^{\circ} \mathrm{C}\right)$ \\
\hline \multicolumn{9}{|c|}{$\mathrm{Cu}-11.85 \mathrm{Al}-3.2 \mathrm{Ni}-3 \mathrm{Mn}$} \\
\hline Suction-cast & $121 \pm 2$ & $128 \pm 1$ & $126 \pm 1$ & $119 \pm 1$ & $104 \pm 4$ & $113 \pm 1$ & 9 & 124 \\
\hline SLM (I-a) & $102 \pm 2$ & $107 \pm 1$ & $106 \pm 2$ & $95 \pm 1$ & $84 \pm 2$ & $90 \pm 1$ & 12 & 101 \\
\hline SLM (I-b) & $102 \pm 1$ & $107 \pm 1$ & $105 \pm 1$ & $96 \pm 1$ & $85 \pm 2$ & $92 \pm 2$ & 11 & 102 \\
\hline SLM (I-c) & $97 \pm 1$ & $104 \pm 1$ & $101 \pm 1$ & $96 \pm 1$ & $78 \pm 2$ & $89 \pm 1$ & 8 & 100 \\
\hline \multicolumn{9}{|c|}{$\mathrm{Cu}-11.35 \mathrm{Al}-3.2 \mathrm{Ni}-3 \mathrm{Mn}-0.5 \mathrm{Zr}$} \\
\hline Suction-cast & $167 \pm 4$ & $178 \pm 3$ & $173 \pm 1$ & $155 \pm 1$ & $143 \pm 3$ & $150 \pm 1$ & 23 & 167 \\
\hline SLM (II-a) & $154 \pm 5$ & $177 \pm 6$ & $166 \pm 5$ & $140 \pm 5$ & $115 \pm 4$ & $132 \pm 5$ & 37 & 159 \\
\hline SLM (II-b) & $152 \pm 4$ & $175 \pm 5$ & $164 \pm 4$ & $139 \pm 4$ & $113 \pm 1$ & $130 \pm 3$ & 36 & 157 \\
\hline SLM (II-c) & $167 \pm 6$ & $190 \pm 6$ & $179 \pm 6$ & $152 \pm 5$ & $125 \pm 7$ & $142 \pm 5$ & 38 & 171 \\
\hline
\end{tabular}

Slices were cut from the central regions of the rods. The characteristic temperatures represent the values from the second cycle. In addition, the thermal hysteresis $T_{\mathrm{H}}$ (difference of $A_{\mathrm{f}}$ and $M_{\mathrm{s}}$ ) and the equilibrium temperature $T_{0}[10]$ are listed 
Table 4 Engineering values of the tensile and the compression tests for $\mathrm{Cu}-11.85 \mathrm{Al}-3.2 \mathrm{Ni}-3 \mathrm{Mn}$ and $\mathrm{Cu}-11.35 \mathrm{Al}-3.2 \mathrm{Ni}-3 \mathrm{Mn}-0.5 \mathrm{Zr}$ at room temperature

\begin{tabular}{|c|c|c|c|c|c|c|c|}
\hline & \multicolumn{3}{|l|}{ Tensile } & \multicolumn{3}{|l|}{ Compression } & \multirow{2}{*}{$\begin{array}{l}\text { Hardness } \\
\text { Micro- hardness } \\
\text { (HV0.1) }\end{array}$} \\
\hline & $\begin{array}{l}\text { Yield strength } \\
(\mathrm{MPa})\end{array}$ & $\begin{array}{l}\text { Fracture } \\
\text { strength }(\mathrm{MPa})\end{array}$ & $\begin{array}{l}\text { Fracture } \\
\text { strain }(\%)\end{array}$ & $\begin{array}{l}\text { Yield strength } \\
(\mathrm{MPa})\end{array}$ & $\begin{array}{l}\text { Fracture } \\
\text { strength }(\mathrm{MPa})\end{array}$ & $\begin{array}{l}\text { Fracture } \\
\text { strain }(\%)\end{array}$ & \\
\hline \multicolumn{8}{|c|}{$\mathrm{Cu}-11.85 \mathrm{Al}-3.2 \mathrm{Ni}-3 \mathrm{Mn}$} \\
\hline Suction-cast & $210 \pm 15$ & $455 \pm 55$ & $4.4 \pm 0.4$ & $240 \pm 30$ & $1515 \pm 50$ & $18 \pm 1.7$ & $210 \pm 22$ \\
\hline SLM (I-a) & $160 \pm 10$ & $620 \pm 50$ & $8.2 \pm 0.9$ & $250 \pm 20$ & $1500 \pm 30$ & $16 \pm 0.2$ & $245 \pm 20$ \\
\hline \multicolumn{8}{|c|}{$\mathrm{Cu}-11.35 \mathrm{Al}-3.2 \mathrm{Ni}-3 \mathrm{Mn}-0.5 \mathrm{Zr}$} \\
\hline Suction-cast & $240 \pm 8$ & $625 \pm 50$ & $5.0 \pm 0.4$ & $260 \pm 10$ & $1395 \pm 50$ & $15 \pm 1.9$ & $235 \pm 8$ \\
\hline SLM (II-c) & $195 \pm 10$ & $470 \pm 15$ & $6.7 \pm 0.5$ & $400 \pm 50$ & $1560 \pm 70$ & $13 \pm 1.8$ & $260 \pm 7$ \\
\hline
\end{tabular}

An overview on the stress-strain curve of selected samples is shown in Figs. 6, 7. The yield strength was determined for a strain offset of $0.2 \%$. The hardness was measured in the central and the border region of suction-cast samples as well as along and perpendicular to the building direction for the SLM material. Values averaged over three samples

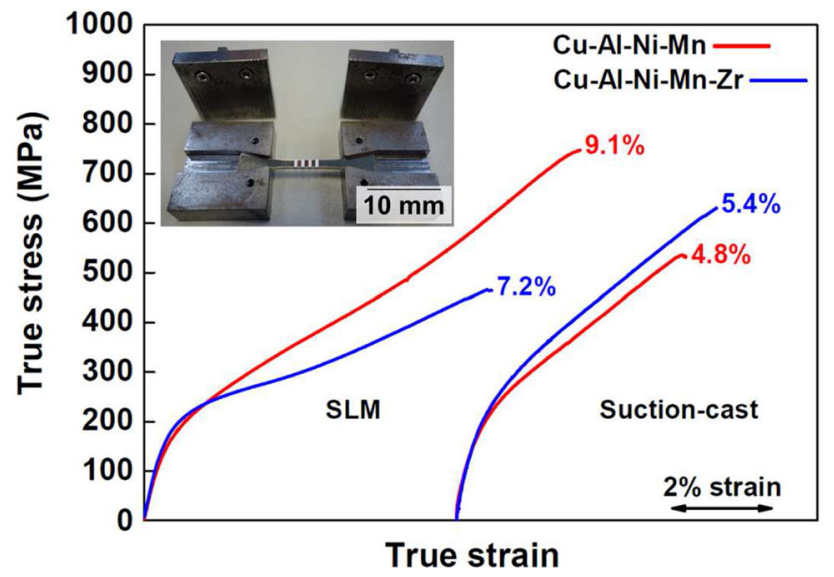

Fig. 6 Selected stress-strain curves in tension for $\mathrm{Cu}-11.85 \mathrm{Al}-$ $3.2 \mathrm{Ni}-3 \mathrm{Mn}$ and $\mathrm{Cu}-11.35 \mathrm{Al}-3.2 \mathrm{Ni}-3 \mathrm{Mn}-0.5 \mathrm{Zr}$ processed by SLM (sample I-a and II-c) and suction casting. The fracture of the fully martensitic samples $\left(\beta_{1}{ }^{\prime}\right)$ occurs at the indicated strains. The average values are listed in Table 4 . The inset shows a tensile sample $(1.5 \mathrm{~mm}$ in thickness) as it was mounted in grips for the testing procedure

$260 \pm 7$ HV0.1 (sample II-c). The measurements for both materials (suction-cast and SLM) were conducted in the centre and near the surface of the samples, and there are no distinct differences in the hardness values for these regions. The increase with the addition of $\mathrm{Zr}$ can be understood in terms of solution hardening of the martensite, and might be also attributed to the formation of the $\mathrm{Cu}_{2} \mathrm{ZrAl}$ phase. Since the grain sizes in all SLM specimens are mostly identical within the experimental error, we can exclude that the grain size contributes to the observed differences in hardness.

Figures 6 and 7 depict the stress-strain curves of selected samples, which were tested in tension and compression, respectively. The differences in hardness also reflect in the measured yield strengths in tension. The values of all tested samples are higher for the $\mathrm{Zr}$-containing

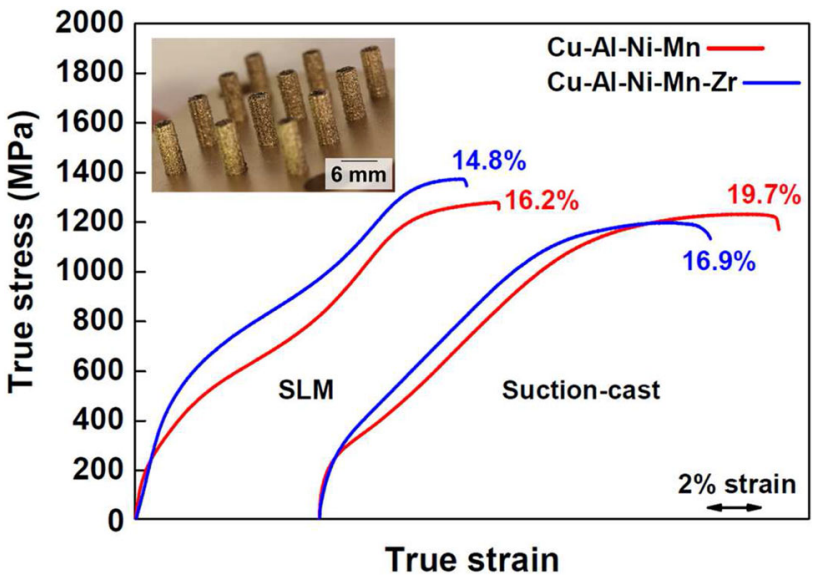

Fig. 7 Selected stress-strain curves in compression for $\mathrm{Cu}-11.85 \mathrm{Al}-$ $3.2 \mathrm{Ni}-3 \mathrm{Mn}$ and $\mathrm{Cu}-11.35 \mathrm{Al}-3.2 \mathrm{Ni}-3 \mathrm{Mn}-0.5 \mathrm{Zr}$ processed by SLM (sample I-a and II-c) and suction casting. The average values of the fully martensitic samples $\left(\beta_{1}{ }^{\prime}\right)$ are listed in Table 4 . The inset depicts the as-build compression samples after SLM processing

alloy. In addition, the yield strength of the suction-cast material $\left(\sigma_{\mathrm{ys}}=210 \pm 15 \mathrm{MPa}\right)$ was found to be increased compared to the SLM specimens (SLM (I-a) $\sigma_{\mathrm{ys}}=160 \pm 10 \mathrm{MPa}$ ) during tensile testing, which might be related to the residual porosity of the SLM samples. The grain size, though, does not seem to have a measureable effect on the yield strength: Owing to non-uniform grain sizes found in all specimens (Table 2) and the relatively small differences in yield strength, it is not possible to establish a solid correlation between yield strength and grain size for the samples obtained by casting or selective laser melting. The fracture strain is constant (about 5\%) in the suction-cast samples (Table 4), but when the two alloys are prepared by means of SLM, the fracture strain increases up to $8.2 \pm 0.9 \%$. Because the grain sizes of all present rapidly quenched $\mathrm{Cu}$-based SMAs are rather small 
Fig. 8 SEM image of suctioncast $\mathrm{Cu}-11.35 \mathrm{Al}-3.2 \mathrm{Ni}-3 \mathrm{Mn}-$ $0.5 \mathrm{Zr}$ after fracture in tension (a). The entire fracture surface is rather rugged, and only few but relatively long cracks propagate during deformation. The Cu-11.35Al-3.2Ni-3Mn$0.5 \mathrm{Zr}$ sample processed by SLM is comparatively smoother and multiple small cracks can be seen (b). The insets display magnified sections of the fracture surfaces. The inset of b depicts a typical pore formed during the SLM process. The fracture surface of the cast $\mathrm{Cu}-$ $11.35 \mathrm{Al}-3.2 \mathrm{Ni}-3 \mathrm{Mn}-0.5 \mathrm{Zr}$ sample does not show any subfeatures at very high magnifications (c). In contrast, dimple-like structures are found on the $\mathrm{Cu}-11.35 \mathrm{Al}-3.2 \mathrm{Ni}-$ $3 \mathrm{Mn}-0.5 \mathrm{Zr}$ sample obtained by SLM. This indicates the increased plastic deformability of the latter sample (cf. Fig. 6)
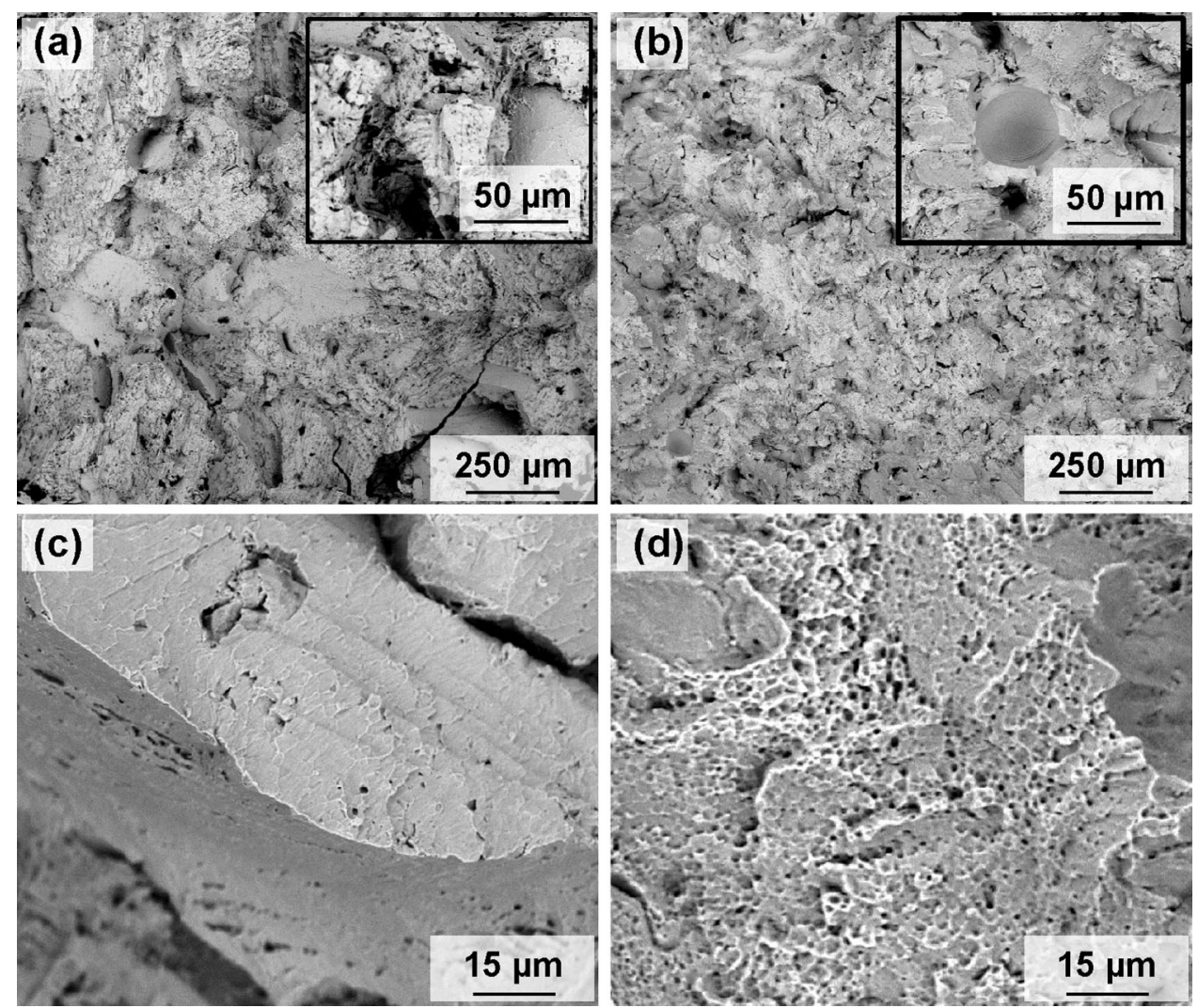

compared to conventionally processed alloys [2], the elastic anisotropy is reduced [2], which in turn improves the plastic deformability [9, 18, 19] and results in the pronounced plastic strain we measure here.

During compressive loading, however, the material behaves in a slightly different manner than in tension. For both alloys, the yield strength is higher for the SLM samples than for the suction-cast rods. This might be caused by the finely dispersed $\mathrm{Cu}_{2} \mathrm{ZrAl}$ particles in the case of the $\mathrm{Cu}-11.35 \mathrm{Al}-3.2 \mathrm{Ni}-3 \mathrm{Mn}-0.5 \mathrm{Zr}$ SLM samples (Fig. 2c). The fracture strength and fracture strain are generally much higher in compression than in tension (Table 4). This asymmetry most likely originates from the residual porosity, which is found in the present SLM samples [31]. The number and size of pores forming during SLM under the present conditions [31] are not detrimental during compressive loading of the two SMAs tested here. Consequently, the SLM samples reach fracture strengths (about $1500 \mathrm{MPa}$ ) and fracture strains (about 15\%) comparable to the fully dense suction-cast specimens. As will be shown below, the differences in the deformability result in different fractographic features.

Both alloys, irrespective of the processing route, exhibit the typical double yielding behaviour in compression and tension [7, 9, 13, 18, 19]. After the elastic region, both alloys overall harden significantly in the plastic regime (Figs. 6, 7). However, the details of the double yielding are different, since the SLM samples exhibit a more pronounced change in the hardening rates in the course of deformation than the suction-cast alloys. All specimens are fully martensitic, and deformation starts in the twinned state [3, 67]. When detwinning sets in, the hardening rate decreases and leads to the first yield point. Elastic loading of the reoriented $\beta_{1}^{\prime}$ martensite reflects in a subsequent increase in the hardening rate $[3,67]$. The critical stress to reorient the martensite variants normally increases with decreasing grain size [18, 19]. This seems to hold for the compression tests (Fig. 7), which suggests that the transition occurrs at higher stresses for the SLM rods. The details of the detwinning process and reorientation of the martensite and the plastic deformation borne by dislocation movement or slip [3, 67] are expected to depend on (i) the orientation of the grains (texture) and (ii) the presence of the $\mathrm{Y}$ phase. As Fig. 2 proves, the SLM samples have a pronounced texture, which arises from an epitaxial-like growth of grains over several layers as well as a preferred lateral growth in certain directions dominated by the anisotropic heat extraction. Suction casting also imposes a gradient in cooling rate and thus a specific texture. These microstructural differences might favour the processes carrying plastic deformation in the SLM samples. Moreover, the Y-phase particles are much finer in the SLM specimens due to the higher cooling rates (Fig. 2). These fine-scale precipitates might not interfere with the 
movement of the twin boundaries to the extent the larger precipitates do. As a possible consequence, the double yielding is less pronounced in the cast specimens. In order to verify this hypothesis, a detailed transmission electron microscopic investigation at various stages of deformation would be required. This, however, is beyond the scope of the present work.

In order to better understand the fracture process, suction-cast and SLM samples after deformation to fracture (under tensile loading) were investigated in the SEM. There are characteristic differences in the morphology of the respective fracture surfaces, which will be discussed in the following only for $\mathrm{Cu}-11.35 \mathrm{Al}-3.2 \mathrm{Ni}-3 \mathrm{Mn}-0.5 \mathrm{Zr}$ alloy. The same observations, however, hold for the $\mathrm{Zr}$-free alloy. Figures $8 \mathrm{a}, \mathrm{b}$ capture almost the entire fracture surface of the samples. The fracture surface of the cast sample (Fig. 8a) is much rougher than that of the SLM sample (Fig. 8b), and intergranular cracking seems to be more pronounced in the cast alloy. Only few but relatively long cracks develop during loading to fracture. In contrast, multiple smaller cracks (about $50 \mu \mathrm{m}$ ) form in the SLM specimen, indicating the higher resistance of this material against crack propagation. The fine-grained regions (Fig. 2c) where melt tracks overlap might promote crack deflection [18, 19]. The insets of Fig. 8a, b represent images taken at a higher magnification. Interestingly, the pore seen in the inset of Fig. $8 \mathrm{~b}$ does not seem to negatively affect the fracture behaviour locally. At higher magnifications, the fracture surface of the cast sample (Fig. 8c) is relatively smooth, while dimple-like features can be found in the SLM specimen. Dimples are generally a sign of ductile fracture, and their presence in the SLM samples is in agreement with their slightly larger plastic strain in tension as well as in compression. Judging from the present fractographic analysis, the different size and distribution of the $\mathrm{Cu}_{2} \mathrm{ZrAl}$ phase (Fig. 2) does not appear to have a bearing on the overall fracture mechanism.

\section{Conclusions}

The shape-memory alloys $\mathrm{Cu}-11.85 \mathrm{Al}-3.2 \mathrm{Ni}-3 \mathrm{Mn}$ and $\mathrm{Cu}-11.35 \mathrm{Al}-3.2 \mathrm{Ni}-3 \mathrm{Mn}-0.5 \mathrm{Zr}$ were successfully processed by SLM. Almost fully dense specimens can be obtained, and both primarily solidify into $\beta_{1}{ }^{\prime}$ martensite. $\mathrm{Cu}_{2} \mathrm{ZrAl}$ ( $\mathrm{Y}$ phase) is observed after the $\mathrm{Zr}$ additions, and its size and distribution depends on the thermal history (cooling rate). During annealing of the suction-cast specimens, this $\mathrm{Zr}$-rich phase mainly precipitates at the grain boundaries and efficiently hampers grain coarsening. In the SLM and suction-cast samples, however, it is relatively fine and uniformly dispersed in the martensite matrix. Its presence seems to be responsible for the jerky character of the reverse martensitic transformation. Consequently, the Y-phase crystals temporarily pin and thus hamper the movement of the interfaces during the reverse martensitic transformation. $\mathrm{Zr}$ is also dissolved in the matrix and up to a critical cooling rate, it is capable of slowing down grain growth leading to a refined microstructure. After annealing, however, the volume fraction of the $\mathrm{Y}$ phase becomes larger and it coarsens, which suppresses the reverse and forward transformation in the observed temperature regime. In general, $\mathrm{Zr}$ additions increase the equilibrium temperature between the martensite and austenite phase. While it is difficult to correlate the differences in the transformation temperatures with the observed grain sizeowing to the gradient microstructures-one finds that the transformation temperatures tend to increase with increasing energy input during the SLM process.

In tension, the SLM samples fail at larger strains than the suction-cast samples, but all the prepared specimens show higher fracture strengths (above $1300 \mathrm{MPa}$ ) and strains (above 15\%) in compression. All samples show a more or less pronounced double yielding typical of shapememory alloys. The present study shows that SLM can be used to produce bulk parts of Cu-based shape-memory alloys with high density, high strength and enhanced plasticity. By adjusting the process parameters, the transformation temperatures and mechanical properties of $\mathrm{Cu}-$ $11.85 \mathrm{Al}-3.2 \mathrm{Ni}-3 \mathrm{Mn}$ and $\mathrm{Cu}-11.35 \mathrm{Al}-3.2 \mathrm{Ni}-3 \mathrm{Mn}-0.5 \mathrm{Zr}$ can be tailored in situ in contrast to conventional manufacturing techniques, which generally require subsequent thermo-mechanical treatments.

Acknowledgements The authors are grateful to A. Voß, H. Bußkamp, S. Neumann and K. Hennig for the experimental support and M. Frey for the preparation of the $\mathrm{Cu}-11.85 \mathrm{Al}-3.2 \mathrm{Ni}-3 \mathrm{Mn}$ ingots. Furthermore, we thank S. Donath and N. Geißler for the technical assistance. C.S. Kiminami, C. Bolfarini and J. Eckert are thanked for stimulating discussions. Financial support by DFG under the Grant No. PA 2275/4-1 is gratefully acknowledged.

\section{References}

1. Mohd Jani J, Leary M, Subic A, Gibson MA (2014) A review of shape memory alloy research, applications and opportunities. Mater Des 56:1078-1113

2. Tadaki T (1998) Cu-based shape memory alloys. In: Otsuka K, Wayman CM (eds) Shape memory materials. Cambridge University Press, Cambridge, pp 97-116

3. Lagoudas DC (2008) Shape memory alloys: modeling and engineering applications. Springer, New York

4. Cava RD, Bolfarini C, Kiminami CS, Mazzer EM, Botta Filho WJ, Gargarella P, Eckert J (2014) Spray forming of Cu-11.85Al-3.2Ni3Mn (wt \%) shape memory alloy. J Alloy Compd 615:602-606

5. Mazzer EM, Kiminami CS, Gargarella P, Cava RD, Basilio LA, Bolfarini C, Botta Filho WJ, Eckert J, Gustmann T, Pauly S (2014) Atomization and selective laser melting of a Cu-Al-Ni-Mn shape memory alloy. Mater Sci Forum 802:343-348 
6. Dadbakhsh S, Speirs M, Kruth J-P, Schrooten J, Luyten J, Van Humbeeck J (2014) Effect of SLM parameters on transformation temperatures of shape memory nickel titanium parts. Adv Eng Mater 16(9):1140-1146

7. Gargarella P, Kiminami CS, Mazzer EM, Cava RD, Basilio LA, Bolfarini C, Botta WJ, Eckert J, Gustmann T, Pauly S (2015) Phase formation, thermal stability and mechanical properties of a $\mathrm{Cu}-\mathrm{Al}-\mathrm{Ni}-\mathrm{Mn}$ shape memory alloy prepared by selective laser melting. Mater Res 18:35-38

8. Niendorf T, Krooss P, Somsen C, Eggeler G, Chumlyakov YI, Maier HJ (2015) Martensite aging-avenue to new high temperature shape memory alloys. Acta Mater 89:298-304

9. Sari U (2010) Influences of $2.5 \mathrm{wt} \% \mathrm{Mn}$ addition on the microstructure and mechanical properties of $\mathrm{Cu}-\mathrm{Al}-\mathrm{Ni}$ shape memory alloys. Int J Miner Metall Mater 17(2):192-198

10. Saud SN, Abu Bakar TA, Hamzah E, Ibrahim MK, Bahador A (2015) Effect of quarterly element addition of cobalt on phase transformation characteristics of $\mathrm{Cu}-\mathrm{Al}-\mathrm{Ni}$ shape memory alloys. Metall Mater Trans A 46A(8):3528-3542

11. Sugimoto K, Kamei K, Nakaniwa M (1990) Cu-Al-Ni-Mn: a new shape memory alloy for high temperature applications. In: Duerig TW, Melton KN, Stöckel D, Wayman CM (eds) Engineering aspects of shape memory alloys. Butterworth-Heinemann Ltd, London, pp 89-95

12. Dasgupta R, Jain AK, Kumar P, Hussain S, Pandey A (2015) Role of alloying additions on the properties of $\mathrm{Cu}-\mathrm{Al}-\mathrm{Mn}$ shape memory alloys. J Alloy Compd 620:60-66

13. Wu MH (1990) Cu-based shape memory alloys. In: Duerig TW, Melton KN, Stöckel D, Wayman CM (eds) Engineering aspects of shape memory alloys. Butterworth-Heinemann Ltd, London, pp 69-88

14. Zou WH, Lam CWH, Chung CY, Lai JKL (1998) Microstructural studies of a $\mathrm{Cu}-\mathrm{Zn}-\mathrm{Al}$ shape-memory alloy with manganese and zirconium addition. Mater Sci Eng A 29(7):1865-1871

15. Sutou Y, Omori T, Wang JJ, Kainuma R, Ishida K (2004) Characteristics of $\mathrm{Cu}-\mathrm{Al}-\mathrm{Mn}$-based shape memory alloys and their applications. Mater Sci Eng A 378:278-282

16. Sutou Y, Omori T, Kainuma R, Ishida K (2008) Ductile Cu-AlMn based shape memory alloys: general properties and applications. Mater Sci Technol 24(8):896-901

17. Lojen G, Gojić M, Anžel I (2013) Continuously cast $\mathrm{Cu}-\mathrm{Al}-\mathrm{Ni}$ shape memory alloy-properties in as-cast condition. J Alloy Compd 580:497-505

18. Mukunthan K, Brown LC (1988) Preparation and properties of fine grain beta-CuAINi strain-memory alloys. Metall Trans A 19A:2921-2929

19. Sure GN, Brown LC (1984) The mechanical properties of grain refinded beta-Cu-Al-Ni strain-memory alloys. Metall Trans A 15A:1613-1621

20. Dutkiewicz J, Czeppe T, Morgiel J (1999) Effect of titanium on structure and martensic transformation in rapidly solidified $\mathrm{Cu}-$ Al-Ni-Mn-Ti alloys. Mater Sci Eng A 273-275:703-707

21. Lee JS, Wayman CM (1986) Grain refinement of a $\mathrm{Cu}-\mathrm{Al}-\mathrm{Ni}$ shape memory alloy by $\mathrm{Ti}$ and $\mathrm{Zr}$ additions. Trans JIM 27(8): 584-591

22. Elst R, Van Humbeeck J, Delaey L (1988) Grain refinement of $\mathrm{Cu}-\mathrm{Zn}-\mathrm{Al}$ and $\mathrm{Cu}-\mathrm{Al}-\mathrm{Ni}$ by $\mathrm{Ti}$ addition. Mater Sci Technol 4:644-648

23. Sugimoto K, Kamei K, Matsumoto H, Komatsu S, Akamatsu K, Sugimoto T (1982) Grain-refinement and the related phenomena in quaternary $\mathrm{Cu}-\mathrm{Al}-\mathrm{Ni}$ shape memory alloys. J Phys IV 43: 761-766

24. Adachi K, Hamada Y, Tagawa Y (1987) Crystal structure of the $\mathrm{x}$-phase in grain-refined $\mathrm{Cu}-\mathrm{Al}-\mathrm{Ni}-\mathrm{Ti}$ shape memory alloys. Scr Metall 21(4):453-458
25. Elst R, Van Humbeeck J, Meeus M, Delaey L (1986) Grain refinement during solidification of beta-Cu based alloys. $\mathrm{Z}$ Metall 77(7):421-424

26. Lee JS, Wayman CM (1986) Grain refinement of $\mathrm{Cu}-\mathrm{Zn}-\mathrm{Al}$ shape memory alloys. Metallography 19:401-419

27. Morawiec H, Lelatko J, Stróz D, Gigla M (1999) Structure and properties of melt-spun $\mathrm{Cu}-\mathrm{Al}-\mathrm{Ni}$ shape memory alloys. Mater Sci Eng A 273-275:708-712

28. Dunne D, Van Humbeeck J, Chandrasekaran M (1990) Effect of quenching rate on the structure and transformation characteristics of a $\mathrm{Cu}-\mathrm{Al}-\mathrm{Ni}-\mathrm{Mn}-\mathrm{Ti}$ shape memory alloy. Mater Sci Forum 56-58:463-468

29. Peng HY, Yu YD, Li DX (1997) High resolution electron microscopy studies of martensite around $\mathrm{Xs}$ precipitates in a $\mathrm{Cu}$ Al-Ni-Mn-Ti shape memory alloy. Acta Mater 45(12):5153-5161

30. Hurtado I, Van Humbeeck J, Ratchev P, Delaey L (1996) Effect of $\mathrm{x}$-phase precipitation on elastic modulus of $\mathrm{Cu}-\mathrm{Al}-\mathrm{Ni}-(\mathrm{Ti})$ (Mn) shape memory alloys. Mater Trans JIM 37(7):1371-1378

31. Gustmann T, Neves A, Kühn U, Gargarella P, Kiminami CS, Bolfarini C, Eckert J, Pauly S (2016) Influence of processing parameters on the fabrication of a $\mathrm{Cu}-\mathrm{Al}-\mathrm{Ni}-\mathrm{Mn}$ shape-memory alloy by selective laser melting. Addit Manuf 11:23-31

32. Pauly S, Löber L, Petters R, Stoica M, Scudino S, Kühn U, Eckert J (2013) Processing metallic glasses by selective laser melting. Mater Today 16(1/2):37-41

33. Yadroitsev I, Gusarov A, Yadroitsava I, Smurov I (2010) Single track formation in selective laser melting of metal powders. J Mater Process Technol 210(12):1624-1631

34. Yadroitsev I, Smurov I (2010) Selective laser melting technology: from the single laser melted track stability to $3 \mathrm{D}$ parts of complex shape. Phys Proced 5:551-560

35. Wu WH, Yang YQ, Huang YL (2007) Direct manufacturing of $\mathrm{Cu}$-based alloy parts by selective laser melting. Chin Opt Lett 5(1):37-40

36. Pogson SR, Fox P, Sutcliffe CJ, O'Neill W (2003) The production of copper parts using DMLR. Rapid Prototyp J 9(5):334-343

37. Zhang B, Chen J, Coddet C (2013) Microstructure and transformation behavior of in situ shape memory alloys by selective laser melting Ti-Ni mixed powder. J Mater Sci Technol 29(9):863-867

38. Thijs L, Kempen K, Kruth J-P, Van Humbeeck J (2013) Finestructured aluminium products with controllable texture by selective laser melting of pre-alloyed AlSi10 Mg powder. Acta Mater 61(5):1809-1819

39. Font J, Cesari E, Muntasell J, Pons J (2003) Thermomechanical cycling in $\mathrm{Cu}-\mathrm{Al}-\mathrm{Ni}$-based melt-spun shape-memory ribbons. Mater Sci Eng A 354:207-211

40. Löber L, Schimansky FP, Kühn U, Pyczak F, Eckert J (2014) Selective laser melting of a beta-solidifying TNM-B1 titanium aluminide alloy. J Mater Process Technol 214(9):1852-1860

41. Bormann T, Schumacher R, Muller B, Mertmann M, de Wild M (2012) Tailoring selective laser melting process parameters for NiTi implants. J Mater Eng Perform 21(12):2519-2524

42. Bormann T, Muller B, Schinhammer M, Kessler A, Thalmann P, de Wild M (2014) Microstructure of selective laser melted nickeltitanium. Mater Charact 94(12):189-202

43. Pauly S, Kosiba K, Gargarella P, Escher B, Song KK, Wang G, Kuhn U, Eckert J (2014) Microstructural evolution and mechanical behaviour of metastable $\mathrm{Cu}-\mathrm{Zr}$-Co alloys. J Mater Sci Technol 30(6):584-589

44. Ahuja B, Karg M, Nagulin KY, Schmidt M (2014) Fabrication and characterization of high strength $\mathrm{Al}-\mathrm{Cu}$ alloys processed using laser beam melting in metal powder bed. Phys Proced 56:135-146

45. Bauereiß A, Scharowsky T, Körner C (2014) Defect generation and propagation mechanism during additive manufacturing by 
selective beam melting. J Mater Process Technol 214(11):25222528

46. Otsuka K, Tokonami M, Shimizu K (1979) Structure analysis of stress-inducted betál martensite in a Cu-Al-Ni alloy by neutron diffraction. Acta Metall 27:965-972

47. Mazzer EM, Kiminami C, Bolfarini C, Cava RD, Botta WJ, Gargarella P (2015) Thermodynamic analysis of the effect of annealing on the thermal stability of a $\mathrm{Cu}-\mathrm{Al}-\mathrm{Ni}-\mathrm{Mn}$ shape memory alloy. Thermochim Acta 608:1-6

48. Newman JA, Schmitt PA, Toth SJ, Deng F, Zhang S, Simpson GJ (2015) Parts per million powder X-ray diffraction. Anal Chem 87(21):10950-10955

49. Swann PR, Warlimont H (1963) The elctron-metallography and crystallography of copper-aluminium martensties. Acta Metall 11:511-527

50. Kennon NF, Dunne DP, Middleton L (1982) Aging effects in copper-based shape memory alloys. Metall Trans A 13A:551-555

51. Agafonov V, Naudot P, Dubertret A, Dubois B (1988) Influence of the aluminium content on the appearance and stability of martensites in the Cu-Al-Ni system. Scr Metall 22(4):489-494

52. Shishkovsky I, Yadroitsev I, Smurov I (2012) Direct selective laser melting of nitinol powder. Phys Proced 39:447-454

53. Ye C, Suslov S, Fei X, Cheng GJ (2011) Bimodal nanocrystallization of NiTi shape memory alloy by laser shock peening and post-deformation annealing. Acta Mater 59(19):7219-7227

54. Adachi K, Shoji K, Hamada Y (1989) Formation of x phases and origin of grain refinement effect in $\mathrm{Cu}-\mathrm{Al}-\mathrm{Ni}$ shape memory alloys added with Titanium. ISIJ Int 29(5):378-387

55. Seguí C, Cesari E, Van Humbeeck J (1991) Phenomenological approach to the coexistence of two types of martensites in $\mathrm{Cu}-\mathrm{Zn}$ Al-Mn alloys. Mater Trans JIM 32(10):898-904

56. Dutkiewicz J, Cesari E, Segui C, Pons J (1991) Response of CuAl-Mn alloys to ageing in beta phase. J Phys IV 1:229-234

57. Recarte V, Pérez-Landazábal JI, Rodríguez, P.P., Bocanegra, E.H., Nó, M.L., San Juan, J (2004) Thermodynamics of thermally induced martensitic transformations in $\mathrm{Cu}-\mathrm{Al}-\mathrm{Ni}$ shape memory alloys. Acta Mater 52(13):3941-3948

58. Sakamoto H, Shimizu K (1989) Effect of heat treatments on thermally formed martensite phases in monocrystalline $\mathrm{Cu}-\mathrm{Al}-\mathrm{Ni}$ shape memory alloy. ISIJ Int 29(5):395-404

59. Fischer, P., Dunne, D., Van Humbeeck, J. (1986) The effect of transformation cycling and ageing on the beta1-gamma prime thermoelastic martensitic transformation in $\mathrm{Cu}-\mathrm{Al}-\mathrm{Ni}$. ICOMAT86; 1986; Nara, Japan: Japan Institute of Metals; pp. 946-951

60. Van Humbeeck J, Van Hulle D, Delaey L, Ortín J, Seguí C, Torra V (1987) A two-stage martensite transformation in a Cu-13.99 mass\% Al-3.5 mass\% Ni alloy. Trans JIM 28(5):383-391

61. Rodriguez P, Guenin G (1990) Thermal ageing behaviour and origin of a Cu-Al-Ni shape memory alloy. Mater Sci Eng A 129:273-277

62. Van Humbeeck J, Chandrasekaran M, Delaey L (1989) The Influence of post quench ageing in the beta-phase on the transformation characteristics and the physical and mechanical properties of martensite in a $\mathrm{Cu}-\mathrm{Al}-\mathrm{Ni}$ shape memory alloy. ISIJ Int 29(5):388-394

63. Kennon NF, Dunne DP (1981) Shape memory behavior. Met Forum 4(3):130-134

64. Attar H, Calin M, Zhang LC, Scudino S, Eckert J (2014) Manufacture by selective laser melting and mechanical behavior of commercially pure titanium. Mater Sci Eng A 593:170-177

65. Otsuka K, Ren XB (2001) Mechanism of martensite aging effects and new aspects. Mater Sci Eng A 312:207-218

66. Gustmann T, Neves A, Kühn U, Gargarella P, Kiminami CS, Bolfarini C, Eckert J, Pauly S (2016) Fabrication of Cu-Al-Ni-Mn shape-memory parts by selective laser melting. In: Müller B (ed) Fraunhofer direct digital manufacturing conference; 2016. Fraunhofer Verlag, Berlin, pp 159-164

67. Duerig TW, Melton KN, Stöckel D, Wayman CM (2013) Engineering aspects of shape memory alloys. Butterworth-Heinemann, London 